Pacific Journal of Mathematics

CHARACTERIZATIONS OF UNIFORM CONVEXITY 


\title{
CHARACTERIZATIONS OF UNIFORM CONVEXITY
}

\author{
W. L. BYNuM
}

In this paper, three new characterizations of uniform convexity of a Banach space $X$ are established. The characterization developed in Theorem 1 resembles the definition of the modulus of smoothness given by J. Lindenstrauss. The characterizations developed in Theorems 2 and 3 are interrelated, both involving the duality map of $X$ into $X^{*}$. The methods used are adapted to give an abbreviated proof of a recent result of $W$. V. Petryshyn relating the strict convexity of $X$ to the duality map of $X$ into $X^{*}$.

The following definitions are included for reference. For a Banach space $X$, the unit sphere of $X$, denoted by $S_{1}$, is the set of all elements of $X$ having norm 1. A Banach space $X$ is uniformly convex if for each $t$ in $(0,2], 2 \delta(t)=\inf \left\{2-\|x+y\|: x, y \in S_{1}\right.$, $\|x-y\| \geqq t\}$ is positive ([1], [2]) (the function $\delta$ is called the modulus of convexity of $X$ ). A direct consequence of this definition is that each of the following conditions is equivalent to $X$ being uniformly convex:

(i) Whenever $\left\{a_{n}\right\}$ and $\left\{b_{n}\right\}$ are sequences in $S_{1}$ such that $\left\|a_{n}+b_{n}\right\| \rightarrow 2$, then $\left\|a_{n}-b_{n}\right\| \rightarrow 0$.

(ii) Whenever $\left\{a_{n}\right\}$ and $\left\{b_{n}\right\}$ are sequences in $X$ such that $\left\|a_{n}\right\| \rightarrow 1,\left\|b_{n}\right\| \rightarrow 1$, and $\left\|a_{n}+b_{n}\right\| \rightarrow 2$, then $\left\|a_{n}-b_{n}\right\| \rightarrow 0$.

(see [3, p. 113] or [9, p. 109]). The modulus of smoothness of $X$ is the function $\rho$ such that for $t \geqq 0$,

$$
2 \rho(t)=\sup \left\{\|x+t y\|+\|x-t y\|-2: x, y \in S_{1}\right\}
$$

([5]). A Banach space $X$ is strictly convex if for each $x$ and $y$ in $S_{1}$ such that $x \neq y$ and each $\lambda$ in $(0,1),\|\lambda x+(1-\lambda) y\|<1$ ([1], [6]). A function $J: X \rightarrow 2^{X *}$ is a duality map of $X$ into $X^{*}$ if for each $x$ in $X, J(x)=\left\{w \in X^{*}:(w, x)(=w(x))=\|w\|\|x\|\right.$ and $\left.\|w\|=\|x\|\right\}$ (see [6] for notation and a list of pertinent literature).

I would like to thank Professor Tosio Kato for suggesting the following formulation of Theorem 1 .

THEOREM 1. Let $\phi$ be a strictly convex and strictly increasing function on $[0,2]$ such that $\phi(1)=1$. Then $X$ is uniformly convex if and only if for each $t$ in $(0,1], \alpha(t)=\inf \{\phi(\|x+t y\|)+$ $\left.\phi(\|x-t y\|)-2: x, y \in S_{1}\right\}$ is positive. 
Proof. Suppose that $X$ is uniformly convex and that there is a $t$ in $(0,1]$ such that $\alpha(t)=0$. Then there exist sequences $\left\{x_{n}\right\}$ and $\left\{y_{n}\right\}$ in $S_{1}$ such that if we let $a_{n}=x_{n}+t y_{n}$ and $b_{n}=x_{n}-t y_{n}$, then $\phi\left(\left\|a_{n}\right\|\right)+\phi\left(\left\|b_{n}\right\|\right) \rightarrow 2$. Since $\phi$ is convex and nondecreasing and $\phi(1)=1,2 \leqq 2 \phi\left(\left(\left\|a_{n}\right\|+\left\|b_{n}\right\|\right) / 2\right) \leqq \dot{\phi}\left(\left\|a_{n}\right\|\right)+\dot{\phi}\left(\left\|b_{n}\right\|\right) \rightarrow 2$ and thus by the strict convexity of $\dot{\phi}$, we have that $\left|\left\|a_{n}\right\|-\left\|b_{n}\right\|\right| \rightarrow 0$. The preceding inequality and the continuity of $\phi^{-1}$ at 1 imply that $\left\|a_{n}\right\|+\left\|b_{n}\right\| \rightarrow 2$ and consequently that $\left\|a_{n}\right\| \rightarrow 1$ and $\left\|b_{n}\right\| \rightarrow 1$. For each $n,\left\|a_{n}+b_{n}\right\|=2$, so the uniform convexity of $X$ implies that $2 t=\left\|a_{n}-b_{n}\right\| \rightarrow 0$, which is contradictory.

Now suppose that $\alpha(t)$ is positive for each $t$ in $(0,1]$. For fixed $x$ and $y$ in $S_{1}$, the function $h(t)=\phi(\|x+t y\|)+\phi(\|x-t y\|)-2$ is convex, and since $h(0)=0$ and $h \geqq 0$ on $[0,1], h$ is nondecreasing. Therefore, since $\alpha$ is the infimum of a collection of nondecreasing functions, $\alpha$ is nondecreasing on $[0,1]$. By the definition of $\alpha$, if $\|y\| \leqq\|x\| \neq 0$, then $\phi(\|x+y\| /\|x\|)+\phi(\|x-y\| /\|x\|)-2 \geqq \alpha(\|y\| /\|x\|)$. Thus if $a$ and $b$ are in $S_{1}$ and $\|a-b\| \leqq\|a+b\|$, we have that

$$
2 \dot{\phi}(2 /\|a+b\|)-2 \geqq \alpha(\|a-b\| /\|a+b\|) \geqq \alpha(\|a-b\| / 2) .
$$

Now, let $\left\{a_{n}\right\}$ and $\left\{b_{n}\right\}$ be sequences in $S_{1}$ such that $\left\|a_{n}+b_{n}\right\| \rightarrow 2$. We may assume that for sufficiently large $n,\left\|a_{n}-b_{n}\right\| \leqq\left\|a_{n}+b_{n}\right\|$. Thus inequality (1) and the continuity of $\phi$ at 1 imply that $\alpha\left(\left\|a_{n}-b_{n}\right\| / 2\right) \rightarrow 0$, so $\left\|a_{n}-b_{n}\right\| \rightarrow 0$ and $X$ is uniformly convex.

Inequality (1) above gives a bound on the modulus of convexity, $\delta$, in terms of $\phi^{-1}$ and $\alpha$. By considering each of the cases $\|a-b\| \leqq\|a+b\|, 1 \leqq\|a+b\| \leqq\|a-b\|, \quad$ and $\|a+b\|<1$, it follows that $2 \delta(\|a-b\|)$ is not less than the smaller of

$$
1 \text {, }\|a-b\|\left\{\phi^{-1}(1+1 / 2 \alpha(1 / 2))-1\right\},
$$

and $\|a-b\|\left\{\phi^{-1}(1+1 / 2 \alpha(\|\alpha-b\| / 2))-1\right\}$.

In Theorem 1, the case when $\phi(t)=t^{2}$ merits special attention. Note that for each Banach space $X$ and each $t$ in $[0,1], \alpha(t) \leqq 2 t^{2}$; moreover, $X$ is an inner product space if and only if $\alpha(t)=2 t^{2}$ for each $t$ in $[0,1]$. In the same vein, note that $X$ obeys a weak parallelogram law (i.e., there is a $\lambda$ in $(0,1]$ such that for each $x$ and $y$ in $X,\|x+y\|^{2}+\lambda\|x-y\|^{2} \leqq 2\|x\|^{2}+2\|y\|^{2}-$ see [4]) if and only if there is a $\mu$ in $(0,2]$ such that $\alpha(t) \geqq \mu t^{2}$ for each $t$ in $[0,1]$.

THEOREM 2. A Banach space $X$ is uniformly convex if and only if for each $t$ in $(0,2], \beta(t)=\inf \left\{1-(f, y): x, y \in S_{1},\|x-y\| \geqq t\right.$, $f \in J(x)\}$ is positive, where $J$ is the duality map from $X$ into $X^{*}$.

Proof. If $X$ is uniformly convex and $x, y \in S_{1}$ and $f \in J(x)$, then 
$1-(f, y)=2-(f, x+y) \geqq 2-\|x+y\| \geqq 2 \delta(\|x-y\|)$.

Now suppose that $\beta>0$ on $(0,2]$ and that $X$ is not uniformly convex. Then by the definition there exist sequences $\left\{x_{n}\right\}$ and $\left\{y_{n}\right\}$ in $S_{1}$ such that $0<\left\|x_{n}+y_{n}\right\| \rightarrow 2$ and for each $n,\left\|x_{n}-y_{n}\right\| \geqq t$. For each $n$, let $a_{n}=\left\|x_{n}+y_{n}\right\|^{-1}, z_{n}=a_{n}\left(x_{n}+y_{n}\right), h_{n} \in J\left(z_{n}\right), f_{n} \in J\left(x_{n}\right)$, and $g_{n} \in J\left(y_{n}\right)$. Then,

$$
\begin{aligned}
& 2-\left\|x_{n}+y_{n}\right\|=1-\left(h_{n}, x_{n}\right)+1-\left(h_{n}, y_{n}\right) \geqq \beta\left(\left\|x_{n}-z_{n}\right\|\right) \\
& \quad+\beta\left(\left\|y_{n}-z_{n}\right\|\right) .
\end{aligned}
$$

But neither $\left\|x_{n}-z_{n}\right\|$ nor $\left\|y_{n}-z_{n}\right\|$ is less than $t a_{n}-\left|1-2 a_{n}\right|$, so that for sufficiently large $n$, we have $\left\|x_{n}-z_{n}\right\| \geqq t / 4,\left\|y_{n}-z_{n}\right\| \geqq t / 4$, and $2-\left\|x_{n}+y_{n}\right\| \geqq 2 \beta(t / 4)$, which is contradictory.

Theorem 3. A Banach space $X$ is uniformly convex if and only if the duality map $J$ of $X$ into $X^{*}$ is uniformly monotone-in the sense that for each $t$ in $(0,2], \gamma(t)=\inf \left\{(f-g, x-y): x, y \in S_{1},\|x-y\| \geqq t\right.$, $f \in J(x), g \in J(y)\}$ is positive.

Proof. If $X$ is uniformly convex and $x, y \in S_{1}, f \in J(x), g \in J(y)$, then $(f-g, x-y)=2-(g, x+y)+2-(f, x+y) \geqq 2(2-\|x+y\|)$, so $J$ is uniformly monotone.

Suppose $J$ is uniformly monotone and $X$ is not uniformly convex. By Theorem $2, \beta(t)=0$ for some $t$ in $(0,2]$; i.e., there exist sequences $\left\{x_{n}\right\}$ and $\left\{y_{n}\right\}$ in $S_{1}$ and $\left\{f_{n}\right\}$ in $X^{*}$ such that for each $n$,

$$
f_{n} \in J\left(x_{n}\right),\left\|x_{n}-y_{n}\right\| \geqq t
$$

and $1-\left(f_{n}, y_{n}\right) \rightarrow 0$. Since $1-\left(f_{n}, y_{n}\right) \geqq 2-\left\|x_{n}+y_{n}\right\| \geqq 0$, then $\left\|x_{n}+y_{n}\right\| \rightarrow 2$ and we may assume that $\left\|x_{n}+y_{n}\right\|>0$ for each $n$. As in Theorem 2, let $a_{n}=\left\|x_{n}+y_{n}\right\|^{-1}, z_{n}=a_{n}\left(x_{n}+y_{n}\right)$, and $h_{n} \in J\left(z_{n}\right)$. Thus, $\left(h_{n}, x_{n}+y_{n}\right)=\left\|x_{n}+y_{n}\right\| \rightarrow 2$ and since $\left\|h_{n}\right\|=1=\left\|x_{n}\right\|=\left\|y_{n}\right\|$, then $\left(h_{n}, x_{n}\right) \rightarrow 1$. So,

$$
\left(h_{n}-f_{n}, z_{n}-x_{n}\right)=1-a_{n}-a_{n}\left(f_{n}, y_{n}\right)+1-\left(h_{n}, x_{n}\right) \rightarrow 0 .
$$

However, as in Theorem 2, for sufficiently large $n$, we have that $\left\|x_{n}-z_{n}\right\| \geqq t / 4$ and $\left(h_{n}-f_{n}, z_{n}-x_{n}\right) \geqq \gamma(t / 4)$, which is contradictory.

Now we turn to the previously mentioned result of Petryshyn [6, Theorem 1, p. 284-287]. We need the following theorem, proved in slightly different form in [8, Theorem, part iii]. We include a proof of it here for completeness. In the sequel, we shall use the following characterization of strict convexity due to Ruston [7]: A Banach space $X$ is strictly convex if and only if for $x$ and $y$ in $S_{1}$ such that $x \neq y, 2-\|x+y\|>0$. 
Theorem (Torrance [8]). A Banach space $X$ is strictly convex if and only if for $x$ and $y$ in $S_{1}$ such that $x \neq y$ and for $f$ in $J(x)$, $1-(f, y)>0$.

Proof. Suppose that $X$ is strictly convex and let $x, y$, and $f$ be as above. Then, $1-(f, y) \geqq 2-\|x+y\|>0$.

Now suppose that the second condition of the theorem is satisfied and that $X$ is not strictly convex. Then, there exist $x, y \in S_{1}(x \neq y)$ such that $\|x+y\|=2$. Let $z=(x+y) / 2$ and $h \in J(z)$. Since $\|h\|=1=\|x\|=\|y\|$ and $(h, x+y)=2,(h, x)=1$, a contradiction, since $z \neq x$.

Theorem (Petryshyn [6]). A Banach space $X$ is strictly convex if and only if the duality map $J$ of $X$ into $X^{*}$ is strictly monotonein the sense that if $x \neq y, f \in J(x)$, and $g \in J(y)$, then $(f-g, x-y)>0$.

Proof. Suppose that $X$ is strictly convex. Let $x, y \in X, f \in J(x)$, and $g \in J(y)$. Then, $\|f\|\|y\|-(f, y) \geqq\|f\|(\|x\|+\|y\|-\|x+y\|)$ and $\|g\|\|x\|-(g, x) \geqq\|g\|(\|x\|+\|y\|-\|x+y\|)$ and by the use of equation $(\#)$ of [6], we have

$$
\begin{aligned}
(f-g, x-y) \geqq & (\|x\|-\|y\|)^{2} \\
& +(\|x\|+\|y\|)(\|x\|+\|y\|-\|x+y\|) .
\end{aligned}
$$

If $x \neq y$ and $\|x\|=\|y\|$, then $\|x\|>0$ and $\|x\|+\|y\|-\|x+y\|=$ $\|x\|(2-\|x /\| x\|+y /\| x\|\|)$, which is positive by the strict convexity of $X$. Consequently, $J$ is strictly monotone.

Now, suppose that $J$ is strictly monotone and that $X$ is not strictly convex. Then by the previous theorem, there exist $x, y \in S_{1}$ $(x \neq y)$ and an $f \in J(x)$ such that $1-(f, y)=0$. As before, $1-(f, y) \geqq 2-\|x+y\|$, so $\|x+y\|=2$. If $z=(x+y) / 2$ and $h \in J(z)$, then $(h, x+y)=2$ and $\|h\|=1=\|x\|=\|y\|$, so $(h, x)=1$. Consequently, $(h-f, z-x)=1-(h, x)+1-(f, z)=0$, which contradicts the fact that $z \neq x$.

\section{REFERENCES}

1. J. A. Clarkson, Uniformly convex spaces, Trans. Amer. Math. Soc., 40 (1936), 396-414.

2. M. M. Day, Uniform convexity in factor and conjugate spaces, Annals of Math., 45 (1944), 375-385.

3. M. M. Day, Normed Linear Spaces, Springer-Verlag, New York, 1962.

4. D. C. Kay, A parallelogram law for certain $L_{p}$ spaces, Amer. Math. Monthly, 74 (1967), 140-147.

5. J. Lindenstrauss, On the modulus of smoothness and divergent series in Banach spaces, Michigan Math. J., 10 (1963), 241-252.

6. W. V. Petryshyn, A characterization of strict convexity of Banach spaces and other uses of duality mappings, J. Functional Analysis, 6 (1970), 282-291. 
7. A. F. Ruston, A note on convexity in Banach spaces, Proc. Cambridge Philos. Soc., 45 (1949), 157-159.

8. E. Torrance, Strictly convex spaces Via semi-inner-product orthogonality, Proc. Amer. Math. Soc., 26 (1970), 108-110.

9. A. Wilansky, Functional Analysis, Blaisdell Publ. Co., New York, 1964.

Received January 7, 1971.

College of William and Mary 



\title{
PACIFIC JOURNAL OF MATHEMATICS
}

\author{
EDITORS
}

\author{
H. Samelson \\ Stanford University \\ Stanford, California 94305 \\ C. R. HOBBY \\ University of Washington \\ Seattle, Washington 98105
}

J. DugundJI

Department of Mathematics

University of Southern California

Los Angeles, California 90007

RICHARD ARENS

University of California

Los Angeles, California 90024

\section{ASSOCIATE EDITORS}

E. F. BECKENBACH
B. H. NEUMANN

F. WoLF
K. YosHIDA

\section{SUPPORTING INSTITUTIONS}

\author{
UNIVERSITY OF BRITISH COLUMBIA \\ CALIFORNIA INSTITUTE OF TECHNOLOGY \\ UNIVERSITY OF CALIFORNIA \\ MONTANA STATE UNIVERSITY \\ UNIVERSITY OF NEVADA \\ NEW MEXICO STATE UNIVERSITY \\ OREGON STATE UNIVERSITY \\ UNIVERSITY OF OREGON \\ OSAKA UNIVERSITY \\ UNIVERSITY OF SOUTHERN CALIFORNIA
}

\author{
STANFORD UNIVERSITY \\ UNIVERSITY OF TOKYO \\ UNIVERSITY OF UTAH \\ WASHINGTON STATE UNIVERSITY \\ UNIVERSITY OF WASHINGTON \\ $\stackrel{*}{*} \stackrel{*}{*} \stackrel{*}{*}{ }^{*}{ }^{*}$ MERICAN MATHEMATICAL SOCIETY \\ CHEVRON RESEARCH CORPORATION \\ NAVAL WEAPONS CENTER
}

The Supporting Institutions listed above contribute to the cost of publication of this Journal, but they are not owners or publishers and have no responsibility for its content or policies.

Mathematical papers intended for publication in the Pacific Journal of Mathematics should be in typed form or offset-reproduced, (not dittoed), double spaced with large margins. Underline Greek letters in red, German in green, and script in blue. The first paragraph or two must be capable of being used separately as a synopsis of the entire paper. The editorial "we" must not be used in the synopsis, and items of the bibliography should not be cited there unless absolutely necessary, in which case they must be identified by author and Journal, rather than by item number. Manuscripts, in duplicate if possible, may be sent to any one of the four editors. Please classify according to the scheme of Math. Rev. Index to Vol. 39. All other communications to the editors should be addressed to the managing editor, Richard Arens, University of California, Los Angeles, California, 90024.

50 reprints are provided free for each article; additional copies may be obtained at cost in multiples of 50 .

The Pacific Journal of Mathematics is published monthly. Effective with Volume 16 the price per volume (3 numbers) is $\$ 8.00$; single issues, $\$ 3.00$. Special price for current issues to individual faculty members of supporting institutions and to individual members of the American Mathematical Society: $\$ 4.00$ per volume; single issues $\$ 1.50$. Back numbers are available.

Subscriptions, orders for back numbers, and changes of address should be sent to Pacific Journal of Mathematics, 103 Highland Boulevard, Berkeley, California, 94708.

PUBLISHED BY PACIFIC JOURNAL OF MATHEMATICS, A NON-PROFIT CORPORATION

Printed at Kokusai Bunken Insatsusha (International Academic Printing Co., Ltd.), 7-17, Fujimi 2-chome, Chiyoda-ku, Tokyo, Japan. 


\section{Pacific Journal of Mathematics}

J. T. Borrego, Haskell Cohen and Esmond Ernest Devun, Uniquely

representable semigroups on the two-cell .................. 565

Glen Eugene Bredon, Some examples for the fixed point property ........ 571

William Lee Bynum, Characterizations of uniform convexity .......... 577

Douglas Derry, The convex hulls of the vertices of a polygon of order $n \ldots 583$

Edwin Duda and Jack Warren Smith, Reflexive open mappings .......... 597

Y. K. Feng and M. V. Subba Rao, On the density of $(k, r)$ integers ........ 613

Irving Leonard Glicksberg and Ingemar Wik, Multipliers of quotients of

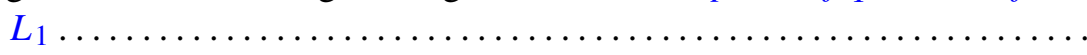

John William Green, Separating certain plane-like spaces by Peano

continua.........................................

Lawrence Albert Harris, A continuous form of Schwarz's lemma in normed

linear spaces .................................... 635

Richard Earl Hodel, Moore spaces and $w$-spaces ............... 641

Lawrence Stanislaus Husch, Jr., Homotopy groups of PL-embedding spaces.

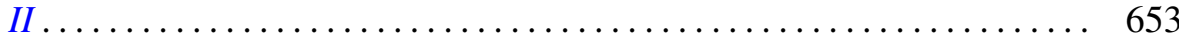

Yoshinori Isomichi, New concepts in the theory of topological

space-supercondensed set, subcondensed set, and condensed set.....

J. E. Kerlin, On algebra actions on a group algebra .................

669

Keizō Kikuchi, Canonical domains and their geometry in $C^{n} \ldots \ldots \ldots \ldots 681$

Ralph David McWilliams, On iterated $w^{*}$-sequential closure of cones. .

697

C. Robert Miers, Lie homomorphisms of operator algebras ..

717

Louise Elizabeth Moser, Elementary surgery along a torus knot ...

737

Hiroshi Onose, Oscillatory properties of solutions of even order differential

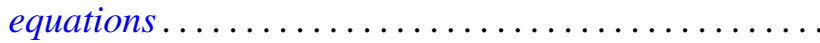

747

Wellington Ham Ow, Wiener's compactification and $\Phi$-bounded harmonic

functions in the classification of harmonic spaces...

Zalman Rubinstein, On the multivalence of a class of meromorphic

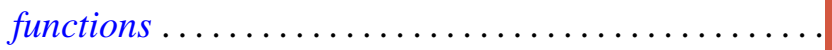

771

785

Hans H. Storrer, Rational extensions of modules

795

topological lattices ...........................

Robert Evert Stong, On the cobordism of pairs .................. 803
Albert Leon Whiteman, An infinite family of skew Hadamard matrices . . . 817

Lynn Roy Williams, Generalized Hausdorff-Young inequalities and mixed

norm spaces 